\title{
PENGARUH STRUKTUR MODAL TERHADAP PROFITABILITAS PERUSAHAAN JASA SUB SEKTOR LEMBAGA PEMBIAYAAN YANG TERDAFTAR DI BURSA EFEK INDONESIA PERIODE 2015-2018
}

\author{
Nazariah $^{(1)}$, Maisur ${ }^{(2)}$ \\ ${ }^{1}$ Akuntansi, UniversitasJabalGafur, Sigli \\ ${ }^{2}$ Manajemen, UniversitasJabalGhafur, Sigli \\ e-mail: nazariah@unigha.ac.id, maisur@unigha.ac.id
}

\begin{abstract}
The purpose of this study was to determine the effect of capital structure on the profitability of financial institutions sub-sector service companies listed on the Indonesian stock exchange for the period 2015-2018. The data analysis technique used in this research is quantitative. Data collection techniques in this study using documentation techniques. In taking the sample using purposive sampling method using certain criteria. The research sample was 10 companies. The results showed that the debt ratio (DR) had no effect on profitability (ROA), while the debt to asset ratio had an effect on profitability (ROA).
\end{abstract}

Keywords : Debt Ratio, Profitability, Debt to Assets Ratio

\begin{abstract}
ABSTRAK
Tujuan penelitian ini dilakukan untuk mengetahui pengaruh struktur modal terhadap profitabilitas perusahaan jasa sub sector lembaga pembiayaan yang terdaftar di bursa efek Indonesia periode 2015-2018. Teknik analisis data yang digunakan dalam penelitian ini adalah kuantitatif. Teknik pengumpulan data dalam penelitian ini menggunakan teknik dokumentasi. Pada pengambilan sampel menggunakan metode purposive sampling dengan menggunakan criteria tertentu. Sampel penelitian sebanyak 10 perusahaan. Hasil penelitian bahwa debt ratio (DR) tidak berpengaruh terhadap profitabilitas (ROA), sedangkan debt to asset ratio berpengaruh terhadap profitabilitas (ROA).
\end{abstract}

Kata kunci: Rasio Hutang, Profitabilitas, rasio hutang terhadap aset

\section{Pendahuluan}

Untuk menghadapi setiap persaingan serta membiayai kegiatan operasionalnya, perusahaan tentu membutuhkan dana. Dana dapat berasal dari dalam perusahaan (modal sendiri) maupun dari luar perusahaan (modal asing). Bagi sebagian besar perusahaan, sumber dari modal sendiri seringkali dirasa kurang, karena perusahaan yang sehat akan mencerminkan efisiensi dalam kinerja perusahaan dan menjadi tuntutan utama untuk bisa bersaing dengan perusahaan lainnya, modal di investasikan dengan tujuan untuk menciptakan keuntungan dan menambah kekayaan bagi pemilik perusahaan supaya dapat memperoleh tingkat keuntungan yang diharapkan diperlukan pengelolaan yang baik, dengan menggunakan struktur modal.

Struktur modal berkaitan dengan jumlah hutang dan modal sendiri yang digunakan untuk membiayai aktivitas perusahaan. Struktur modal yang efektif mampu menciptakan perusahaan dengan keuangan yang kuat dan stabil (Sartono, 2010).

Struktur modal juga merupakan perimbangan antara penggunaan hutang 
(debt) baik hutang jangka panjang maupun jangka pendek terhadap modal sendiri (equity). Untuk menganalisis efek struktur modal terhadap profitabilitas salah satu teori yang dikaji adalah pecking order theory. Dimana teori ini menjelaskan mengapa perusahaan akan meneruskan hierarki sumber pendanaan yang paling disukai (Putra, 2013).

Penentuan struktur modal memiliki keterkaitan dengan hutang perusahaan, yaitu perusahaan dapat melakukan hutang khususnya hutang jangka panjang. Hutang atau leverage dapat diukur dengan menggunakan Debt Ratio (DR) dan Debt to Equity Ratio (DER). "Debt Ratio merupakan rasio hutang yang digunakan untuk mengukur perbandingan antara total hutang dengan total aktiva". Sedangkan, "Debt to Equity Ratio merupakan rasio yang digunakan untuk menilai hutang dengan ekuitas"(Kasmir, 2013). Sedangkan Brigham \& Houston (2010:143) menyatakan bahwa "Perusahaan yang lebih banyak menggunakan hutang dalam operasinya, akan mendapatkan beban bunga yang lebih tinggi, sehingga beban bunga tersebut akan menurunkan laba bersih". Dengan demikian, adanya penggunaan hutang akan mempengaruhi resiko dan keuntungan yang diperoleh perusahaan.

Hal ini berarti bahwa jika penggunaan hutang perusahaan meningkat maka profitabilitas akan menurun, begitu juga sebaliknya. Semakin besar tingkat profitabilitas akan memperlihatkan kinerja manajemen yang baik dalam mengelola perusahaan serta meningkatkan kemakmuran bagi pemilik perusahaan. Rasio profitabilitas merupakan rasio untuk menilai kemampuan perusahaan dalam mencapai keuntungan.

Rasio Profitabilitas dapat diukur dengan menggunakan Return On Assets (ROA). Return On Assets merupakan pengukuran kemampuan perusahaan secara keseluruhan di dalam menghasilkan keuntungan dengan jumlah keseluruhan aktiva yang tersedia pada perusahaan.

$$
\text { Berdasarkan hasil penelitian }
$$

Purwitasari dan Septiani, (2013) Penggunaan hutang dengan tingkat suku bunga tertentu berpengaruh besar terhadap ROA, karena semakin tinggi tingkat suku bunga maka akan semakin besar beban bunga yang harus dibayarkan. Perusahaanperusahaan yang kurang profitable cenderung mempunyai hutang yang lebih besar karena dua alasan internal yang tidak mencukupi kebutuhan dan karena hutang merupakan sumber eksternal yang lebih disukai.

\section{Metode}

Populasi dalam penelitian ini yaitu seluruh perusahaan Jasa Sub Sektor LembagaPembiayaan yang terdaftar di BEI, yang berjumlah 17 perusahaan. Pada penelitian ini menggunakan purposive sampling dengan kriteria di atas, dan setelah data perusahaan didokumentasi sesuai dengan kriteria yang telah ditetapkan, maka diperoleh sampel dalam penelitian ini yaitu sebanyak 11 perusahaan dengan periode penelitian yaitu 2015-2018.

Jenis data yang diperlukan dan dikumpulkan dalam penelitian ini ialah data kuantitatif.Analisis data adalah kegiatan mengolah data yang telah dikumpulkan menjadi perangkat hasil dan penemuan baru atau dalam bentuk pembuktian dari hipotesis. Metode analisis data ini dengan menggunakan bantuan program SPSS for windows.

Adapun bentuk matematisnya regresi linier sederhana sebagai berikut:

$\mathrm{Y}=\alpha+\beta_{1} \mathrm{X}_{1}+\beta_{2} \mathrm{X}_{2}+\mathrm{e}$

$\mathrm{Y}=$ Profitabilitas (ROA)

$\alpha=$ Nilai Konstanta

$\beta=$ Koefisien Regresi variabel

$\mathrm{X}_{1}=$ Debt Ratio (DR)

$\mathrm{X}_{2}=$ Debt To Equity Ratio(DER)

$\varepsilon=$ error 
Jurnal Sosial Humaniora Sigli (JSH)

p ISSN : 2615-3688

$e$ ISSN : 2716-0270

http://journal.unigha.ac.id/index.php/JSH

\section{Hasil dan Pembahasan}

Data penelitian dikatakan normal apabila nilai Asymp.Sig (2-tailed) variable berada diatas 0,05 atau $5 \%$, maka sebaliknya apabila Asymp.Sig (2-tailed) variable berada dibawah 0,05 atau 5\% maka data tersebut tidak berdistribusi secara normal. Hasil yang diperoleh dari uji normalitas dapat dilihat pada tabel1 sebagai berikut:

Tabel 1 HasilUjiNormalitas One-Sample Kolmogorov-Smirnov Test

\begin{tabular}{|ll|r|}
\hline & & $\begin{array}{c}\text { Unstandardized } \\
\text { Residual }\end{array}$ \\
\hline $\mathrm{N}$ & Mean & 40 \\
Normal Parameters & Std. & $0 \mathrm{E}-7$ \\
& Deviation & 3.02601617 \\
Most Extreme & Absolute & .143 \\
Differences & Positive & .122 \\
Kolmogorov-Smirnov Z & -.143 \\
Asymp. Sig. (2-tailed) & .903 \\
\hline
\end{tabular}

a. Test distribution is Normal.

b. Calculated from data.

Berdasarkan tabel 4. Diatas diketahui bahwa jumlah data yang diteliti $(\mathrm{N})$ adalah 40 data, setelah di uji normalitas maka terdapat nilai signifikan sebesar 0,389. Karena nilai signifikan 0,243 lebih besar dibandingkan tingkat signifikansi 0,05 atau $5 \%$ maka hal ini berarti asumsi normalitas terpenuhi.

Pengujian statistic dengan alat analisis regresi linier berganda dimaksudkan untuk mengetahui pengaruh struktur modal yang diukur dengan Debt Ratio (DR) dan debt to asset Ratio (DER) terhadap profitabilitas. Hasil analisis linier berganda dapat dilihat pada Tabel 2 sebagai berikut:
Tabel 2.Regresi linier berganda

\begin{tabular}{|c|c|c|c|c|c|}
\hline \multicolumn{6}{|c|}{ Coefficients $^{\mathrm{a}}$} \\
\hline \multirow[t]{2}{*}{ Model } & \multicolumn{2}{|c|}{$\begin{array}{l}\text { Unstandardize } \\
\text { d Coefficients }\end{array}$} & $\begin{array}{l}\text { Standa } \\
\text { rdized } \\
\text { Coeffi } \\
\text { cients } \\
\end{array}$ & \multirow[t]{2}{*}{$\mathrm{T}$} & \multirow[t]{2}{*}{ Sig. } \\
\hline & B & $\begin{array}{l}\text { Std. } \\
\text { Error }\end{array}$ & Beta & & \\
\hline \multirow{4}{*}{$\begin{array}{l}\text { (Consta } \\
1 \mathrm{nt)} \\
\mathrm{DR} \\
\mathrm{DAR} \\
\end{array}$} & 6.653 & \multirow{4}{*}{$\begin{array}{r}1.485 \\
2.831 \\
.253\end{array}$} & \multirow{4}{*}{$\begin{array}{l}-.141 \\
-.596\end{array}$} & 4.479 & \multirow{4}{*}{$\begin{array}{l}.000 \\
.398 \\
.001\end{array}$} \\
\hline & & & & -.855 & \\
\hline & 2.422 & & & & \\
\hline & \begin{tabular}{|l}
-.916 \\
\end{tabular} & & & 3.620 & \\
\hline
\end{tabular}

a. Dependent Variable: ROA

Berdasarkan hasil perhitungan menggunakan SPSS versi 20, variable Debt Ratio (DR) tidak berpengaruh secara signifikan terhadap profitabilitas (ROA) sedangkan Debt to Equity Ratio (DER) berpengaruh secara signifikan terhadap variable dependen yaitu ROA dengan nilai signifikannya.

\section{Hasil Uji Hipotesis Pengaruh Debt Ratio $\left(\mathrm{X}_{1}\right)$ terhadap ROA (Y).}

Nilai koefisien regresi parsial dari Debt Ratio mempunyai nilai $\mathrm{t}_{\text {hitung }}(-0,855)$ $<\mathrm{t}_{\text {tabel }}(1,683)$ dan nilai sig $(0,398)>\alpha(0,05)$ maka dapat disimpulkan bahwa $\mathrm{H}_{0}$ diterima dan $\mathrm{H}_{1}$ ditolak, yang berarti Debt Ratio secara parsial tidak berpengaruh secara signifikan terhadap ROA. Artinya Bahwa semakin tinggi debt ratio semakin besar jumlah modal pinjaman yang digunakan di dalam menghasilkan keuntungan bagi perusahaan. Semakin besar rasio hutang (debt ratio) maka perusahaan tersebut memiliki risiko yang besar pula karena semakin besar beban aset yang akan digunakan oleh perusahaan untuk menjamin hutang. Semakin kecil rasio hutang maka menunjukkan hutang yang ditanggung oleh perusahaan tersebut rendah sehingga hal ini akan direspon positif oleh para investor di pasar modal. Pada kondisi yang seperti itulah harga saham di pasar modal akan bergerak naik karena respon positif 
menunjukkan adanya kenaikan jumlah permintaan saham. Dengan demikian dapat dikatakan bahwa debt ratio memiliki pengaruh negatif yang signifikan terhadap harga saham di pasar modal. Hasil penelitian ini sesuai dengan penelitian yang dilakukan oleh Imadudin (2014) dimana hasil penelitiannya debt ratio tidak berpengaruh terhadap return on asset (ROA).

\section{Hasil Uji Hipotesis Pengaruh Debt to Asset Ratio (DAR) terhadap ROA (Y).}

Nilai koefisien regresi parsial dari Debt to Asset Ratio mempunyai nilai $\mathrm{t}_{\text {hitung }}$ ($3,620)<\mathrm{t}_{\text {tabel }}(1,683)$ dan nilai sig $(0,001)<$ $\alpha(0,05)$ maka dapat disimpulkan bahwa $\mathrm{H}_{0}$ ditolak dan $\mathrm{H}_{2}$ diterima, yang berarti Debt to Asset Ratio secara parsial t berpengaruh secara signifikan terhadap ROA. Artinya, Debt to Asset Ratio menurun bias disebabkan adanya total hutang yang menurun dan tidak efektifnya pengelolaan aktiva sehingga laba belum maksimal mengakibatkan laba bersih ikut menurun.

Adapun yang harus di perhatikan oleh perusahan yaitu dalam kegiatan operasi perusahaan itu sendiri. Dari hasil pengukuran, apabila rasionya tinggi, artinya pendanaan dengan utang semakin banyak, maka semakin sulit bagi perusahaan untuk memperoleh tambahan pinjaman karena dikhawatirkan perusahaan tidak mampu menutupi utang-utangnya dengana ktiva yang dimilikinya. Adapun hasil penelitian terdahulu (Pratiwi, 2017) menyatakan bahwa tingkat perputaran Debt to Asset Ratio berpengaruh positif terhadap Return on Asset. Jika perusahaan memutuskan menetapkan struktur modal dalam jumlah yang besar, kemungkinan tingkat likuiditas akan terjaga namun kesempatan untuk memperoleh laba yang besar akan menurun yang pada akhirnya berdampak pada menurunnya profitabilitas. Dari hasil pengukuran, apabila rasionya tinggi, artinya pendanaan dengan utang semakin banyak, maka semakin sulit bagi perusahaan untuk memperoleh tambahan pinjaman karena dikhawatirkan perusahaan tidak mampu menutupi utang-utangnya dengan aktiva yang dimilikinya.

\section{Simpulan dan Saran \\ Kesimpulan}

Berdasarkan hasil penelitian menunjukan bahwa Debt Ratio (DR) tidak berpengaruh terhadap Return On Asset (ROA), Debt to Asset Ratio (DAR) tidak berpengaruh terhadap ROA pada perusahaan jasa Sub Sektor Lembaga Pembiayaan. Debt Ratio (DR) dan Debt to Asset Ratio (DAR) berpengaruh secara bersama-sama terhadap ROA.

\section{Saran-Saran}

Investor sebaiknya memahami semua informasi dengan memperhatikan rasio-rasio lain yang berhubungan dengan profitabilitas yang akan digunakan untuk pengambilan keputusan berinvestasi. Peneliti selanjutnya sebaiknya melakukan penelitian pada sektor yang berbeda dengan jumlah sampel yang lebih banyak agar hasil penelitian memiliki cakupan yang lebih luas.

\section{Daftar Pustaka}

Imadudin, Z. S. (2014). Pengaruh Struktur Modal Terhadap. Jurnal Wawasan Manajemen, 2, 81-96.

Kasmir. (2013). Analisis Laporan Keuangan. Edisi 1. Cetakan ke-6. Jakarta: Rajawali Pers.

Pratiwi, K. (2017). Pengaruh Struktur Modal Dan Profitabilitas Terhadap Harga Saham (Studi Pada Perusahaan Asuransi Yang Terdaftar Di Bursa Efek Indonesia Tahun 2012-2015). Jurnal Administrasi Bisnis S1 Universitas Brawijaya, 45(1), 145-154.

Purwitasari, E., \& Septiani, A. (2013). Analisis Pengaruh Struktur Modal Terhadap Profitabilitas. Acounting, 2(3), 1-11.

Putra, I. (2013). Pengaruh Tingkat Perputaran Kas, Piutang Dan Jumlah Nasabah Kredit Pada Profitabilitas Lpd Di Kecamatan Ubud. E-Jurnal Akuntansi, 3(1), 119-135.

Sartono, A. (2010). Manajemen Keuangan Teori dan Aplikasi (4th ed). Yogyakarta : BPFE. 